\title{
Craniofacial Features Among Children With Bruxism: A Systematic Review
}

Research Article

Deepa Gurunathan ${ }^{1 *}$, Nivedhitha $\mathrm{MS}^{2}$, Joyson Moses ${ }^{3}$, Mahesh Ramakrishnan ${ }^{4}$

${ }^{1} \mathrm{PhD}$ Scholar,Department of Pediatric and Preventive Dentistry, Saveetha Dental College and Hospitals, Saveetha Institute of Medical and Technical Sciences, Saveetha University, Chennai - 600 077, Tamilnadu, India.

${ }^{2}$ Professor, Department of Conservative Dentistry and Endodontics, Saveetha Dental College and Hospitals, Saveetha Institute of Medical and Technical Sciences, Saveetha University, Chennai - 600 077, Tamilnadu, India.

${ }^{3}$ Professor, Department of Pediatric and Preventive Dentistry, Saveetha Dental College and Hospitals, Saveetha Institute of Medical and Technical Sciences, Saveetha University, Chennai - 600 077, Tamilnadu, India.

${ }^{4}$ Reader, Department of Pediatric and Preventive Dentistry, Saveetha Dental College and Hospitals, Saveetha Institute of Medical and Technical Sciences, Saveetha University, Chennai - 600 077, Tamilnadu, India.

\section{Abstract}

Bruxism is a repetitive jaw-muscle activity characterized by clenching or grinding of the teeth and/or by bracing or thrusting of the mandible which can occur either during sleep or during wakefulness. Bruxism has become one of increasing concern among children as it has a negative impact on quality of life and is prevalent among 40 percent of children.As a result of mechanical grinding either during night or day time, bruxism in children leads to tooth wear, tooth mobility, tongue/cheek indentation, masticatory muscle hypertrophy, facial pain and head ache. The changes in the oro-facial region due to bruxism, calls for an early diagnosis and management of bruxism in children. The objective of this systematic review is to systematically evaluate the craniofacial changes associated with bruxism in children. An electronic search of the following databases which includes PubMed, ScienceDirect, Google Scholar and Cochrane were performed till Dec 2018.The results of the systematic review indicate attrition of teeth as a common outcome of grinding of teeth along with other consequences that includes changes in palatal morphology and hypertrophy of masticatory muscles. However, studies with similar criteria for diagnosis of bruxism is required to determine the craniofacial changes.

\section{Introduction}

Bruxism is defined as the "repetitive jaw-muscle activity characterized by clenching or grinding of the teeth and/or by bracing or thrusting of the mandible.This can occur either during sleep or during wakefulness.

The occurrence of bruxism is more common in children and it decreases with age and is less common in adults [1, 2]. According to Manfredini et al. [2] the prevalence of the bruxism in children across the globe ranges from 3.5 to $40.6 \%$, and does not show gender preference. In the recent times, bruxism has become one of increasing concern among children as it has a negative impact on quality of life. As a result of mechanical grinding either during night or day time, bruxism in children leads to tooth wear, tooth mobility, tongue/cheek indentation, masticatory muscle hypertrophy [3-5] temporomandibular disorder s[6], headaches [7], palatal changes and masticatory muscle pain or fatigue breathing disorders during sleep [8-10]. Functional disturbances of the masticatory system are found to be common in children aged between 7 and 14 years with 64\% experiencing pain on muscle palpation and $39 \%$ experiencing pain on TMJ palpation [11].

In addition due to axial forces generated in children with bruxism, it acts as an adjuvant force causing progression of destructive periodontal disease in children [12]. The parafunctional habit also contributes to the development of false Class III, acceler $\neg$ ated root resorption of deciduous teeth and changes in the chronology of permanent teeth eruption and promotion of dental crowding [13]. Thus, this habit should be diagnosed and managed as early

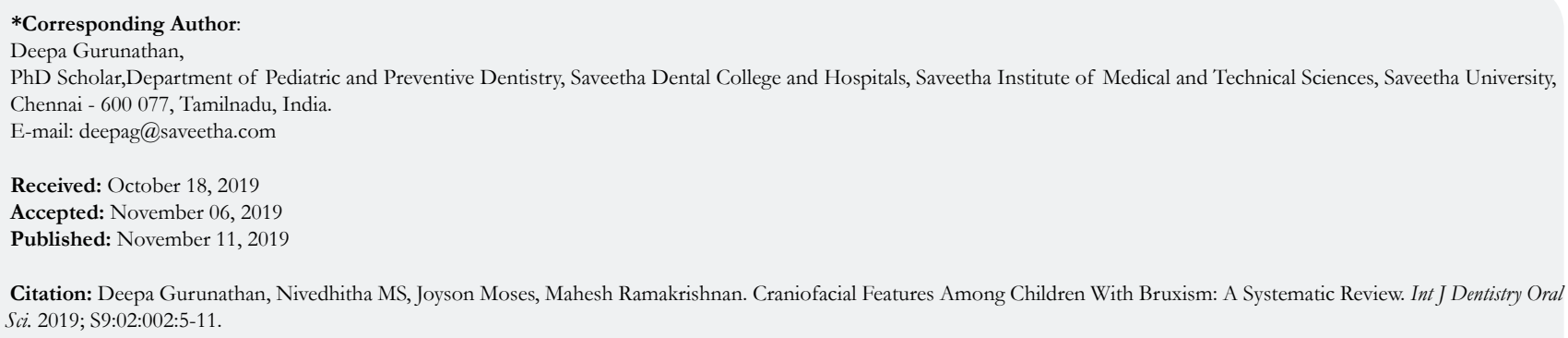

Copyright: Deepa Gurunathan ${ }^{2019}$. This is an open-access article distributed under the terms of the Creative Commons Attribution License, which permits unrestricted use, distribution and reproduction in any medium, provided the original author and source are credited. 
as possible [13]. Though studies have indicated a relation between bruxism and respiratory alterations $[9,10,14]$ the effect of Bruxism on orofacial maturity and speech are still not well established. The numerous changes in the orofacial region due to grinding of teeth, calls for an early diagnosis and management of bruxism in children.

The various oral manifestations due to bruxism in children must be assessed by the dentists to arrive at a more accurate diagnosis of bruxism. Since, there is a lack of uniformity and standardization of criteria to assess the signs and symptoms of bruxism in children, a systematic and critical analysis of current literature is essential to obtain precise data of craniofacial features of children with bruxism.

The objective of this systematic review is to systematically evaluate the craniofacial changes associated with bruxism in children.

\section{Materials and Methods}

The present systematic review was registered in PROSPERO (CRD42018108124). The authors also followed the recommendations of the PRISMA statement during formulation of systematic review14. The PECO methodology was utilized to formulate the research question which was "To identify the craniofacial manifestations of children aged between 3 to 17 years with bruxism.”.

\section{Search Strategy}

An electronic search of the following databases which includes PubMed, ScienceDirect, Google Scholar and Cochrane were performed till Dec 2018. And a hand search of reference list in the selected articles were performed to recognize publications if not identified by electronic search. Articles only in English language were considered for inclusion in the systematic review. Case series and observational studies of the craniofacial features in children with bruxism aged between 3 to 17 years were included for review. Review studies that included both narrative and systematic reviews, letters to the editor, case reports, animal studies, studies without age discrimination, studies involving children with special health care needs were excluded from the review.

The following search strategy was used :(((((Children) OR Kids) OR younger age $))$ AND ((((Grinding of teeth) OR Sleep bruxism) OR Tooth clenching) OR Bruxism $)))$ AND $((((()(((()((($ Tooth wear) AND Occlusal wear) AND Attrition of teeth)) OR (((anterior crossbite) OR posterior crossbite) OR transverse occlusal relationships)) OR Periodontal disease) OR Masseter muscle activity) OR Facial pain) OR Bone loss) OR Periodontitis) OR Gingivitis) OR Palatal morphology) OR Sensitivity of teeth) OR Head ache) OR (((Temporomandibular Joint pain) OR TMJ pain) OR Temporomandibular joint disorder)).

The initial list of articles, assessed by title and abstract, was submitted for review by two independent reviewers (MSN, DG) who applied inclusion criteria and exclusion criteria to determine the final sample. Should there be disagreement between the results of reviewers, a third reviewer (JM) was called in for consensus.

A total of 223 potentially relevant records were found: 219 articles from PubMed, 8 publications from Scopus, 8 publications from WEB OF SCIENCE, none form Cochrane Library, 13 publications from google scholar. After the duplicate references were removed, a total of 219 studies were available for further analysis. Based on titles and abstracts verification 11 articles were selected for the systematic review.

\section{Data Extraction}

Following data was extracted for the selected 11 studies: author names, year of publication, total sample size, sample sex, sample age, diagnosis of bruxism, classification of bruxism, according to the period that occurred and the pattern, occlusal characteristics, palatal morphology, transverse relationship, temporomandibular joint disorders, drooling of saliva, masticatory muscle hyperactivity. (Table 1)

\section{Diagnostic Criteria of Bruxism}

The diagnosis of bruxism was made by parents or guardians in most of the studies and 2 used clinical examination. Despite the wide variety of diagnostic forms for bruxism, $30 \%$ used the American Academy of Sleep Medicine 15 criteria and the other questionnaires were prepared by authors or used questionnaires from previous studies [16]. New Castle Ottawa Scale was used to assess the quality of the studies [17]. (Table 2 and Table 3)

\section{Study selection}

\section{Study characteristics}

Edward V. Kuch (1979) [19] is a case control study showed 15.5\% children out of 358 children showing bruxism. When compared with the controls there was no significant difference in the eight psychological traits evaluated namely conformity, masculinity femininity, maturity, aggression, inhibition, activity level, sleep disturbance and somatization.

C. C. RESTREPO (2008) [20] is a case control study comparing 23 children with bruxism with 23 controls for changes in form of palate in sagittal, frontal and horizontal plane. There was a statistically significant difference in the sagittal plane between bruxers and non-bruxers.

BahmanSeraj (2010) [21] is a cross-sectional descriptive study carried out on 600 children aged 4-12 years. This was a questionnaire based study which found $26.2 \%$ of prevalence for bruxism in the population. The present study reveals drooling as the most common sleep disorder in children with bruxism. In addition, the prevalence of bruxism was higher in children with temporomandibular disorder.

Carra MC, Huynh N (2011) [22] is a case control study where 604 children seeking orthodontic treatment were evaluated for bruxism and compared with controls for jaw muscle fatigue, headache and loud breathing during sleep. This study shows sleep and wake time bruxism to be associated with signs and symptoms suggestive of TMDs and sleep and behavioral problems.

Maryam Ghafournia (2012) [23] is a case control study who examined 400 children and divided them into bruxers and non-bruxers. This study found statistically significant changes in the bruxers 
Table 1. Characteristics of included studies.

\begin{tabular}{|c|c|c|c|c|c|c|c|c|}
\hline $\begin{array}{c}\text { Author and } \\
\text { Year }\end{array}$ & Year & $\begin{array}{l}\text { Place } \\
\text { of } \\
\text { study }\end{array}$ & $\begin{array}{l}\text { Age of } \\
\text { Partici- } \\
\text { pants }\end{array}$ & $\begin{array}{l}\text { Sample } \\
\text { size }\end{array}$ & $\begin{array}{l}\text { Type of } \\
\text { study }\end{array}$ & $\begin{array}{c}\text { Diagnostic Criteria of } \\
\text { Bruxism }\end{array}$ & $\begin{array}{l}\text { Preva- } \\
\text { lence }\end{array}$ & Orofacial features \\
\hline $\begin{array}{l}\text { EdwardV } \\
. \text { Kuch19 } \\
\end{array}$ & 1979 & $\begin{array}{c}\text { Minne- } \\
\text { sota }\end{array}$ & $\begin{array}{c}5 \text { - to } \\
\text { 6-year-old }\end{array}$ & 358 & & $\begin{array}{c}\text { Parental awareness of habit } \\
\text { Clinical examination }\end{array}$ & $24.60 \%$ & 54 children had wear facets \\
\hline $\begin{array}{l}\text { C. C. RE- } \\
\text { STREPO20 }\end{array}$ & 2008 & $\begin{array}{l}\text { Colum- } \\
\text { bia }\end{array}$ & & & $\begin{array}{l}\text { Case } \\
\text { Control } \\
\text { study }\end{array}$ & $\begin{array}{c}\text { AASM criteria15 } \\
\text { The maxillary dental } \\
\text { arches of all subjects were } \\
\text { reproduced } \\
\text { from alginate impressions } \\
\text { cast in dental stone. }\end{array}$ & & $\begin{array}{l}\text { Bruxist children had higher } \\
\text { palate in the frontal plane than control children, } \\
\text { especially in correspondence of the thrid, fourth } \\
\text { and fifth teeth. } \\
\text { Both intercanine and interfourthteeth width were } \\
\text { slightly larger in the bruxist children than in } \\
\text { the control children, with mean differences of } \\
0 Æ 8-0 Æ 9 \mathrm{~mm}\end{array}$ \\
\hline $\begin{array}{c}\text { Bah- } \\
\text { manSeraj21 }\end{array}$ & 2010 & Tehran & 4 to 12 & 600 & $\begin{array}{c}\text { Cross } \\
\text { sectional }\end{array}$ & Questionnaire & $26.20 \%$ & $\begin{array}{c}\text { Parasomnias were stated by parents in } 53.2 \% \\
\text { of children, drooling being the most }(25.8 \%) \text {, } \\
3.2 \% \text { of children had } \\
\text { sleepwalking. } \\
\text { Frequency of joint } \\
\text { click was } 1.2 \% \text {, facial muscles pain } 0.7 \% \text {, } \\
\text { limitation of opening the mouth } 2 \% \text {, and pain } \\
\text { during opening the mouth } 0.7 \% \text {. The prevalence } \\
\text { of bruxism in children with TMD was } 63.6 \% \\
\text { and } \\
\text { in children without TMD } 24.7 \% \text {; the difference } \\
\text { was significant }(\mathrm{P}<0.001)\end{array}$ \\
\hline $\begin{array}{l}\text { Carra MC, } \\
\text { Huynh N22 }\end{array}$ & 2011 & & 7 to 17 & 604 & $\begin{array}{l}\text { Cross } \\
\text { sectional } \\
\text { study }\end{array}$ & $\begin{array}{c}\text { The facial evaluation } \\
\text { included profile analysis } \\
\text { (convex, straight, or } \\
\text { concave), frontal view for } \\
\text { facial thirds } \\
\text { analysis (brachyfacial, } \\
\text { mesofacial, or dolicofa- } \\
\text { cial), and } \\
\text { mandibular plane angle } \\
\text { visualization (flat, nor- } \\
\text { mal, or } \\
\text { steep). Asymmetries of the } \\
\text { facial to dental midlines } \\
\text { were } \\
\text { noted. Tonsil size (normal } \\
\text { or hypertrophy with }>50 \% \\
\text { obstruction), tongue size } \\
\text { (small, normal, large, or } \\
\text { scalloped), } \\
\text { lateral mandibular move- } \\
\text { ments (normal or limited), } \\
\text { amount of overjet, amount } \\
\text { of overbite, and maximal } \\
\text { mouth } \\
\text { opening were also assessed. } \\
\text { Palatal vault shape was } \\
\text { noted as } \\
\text { being deep, round, or flat. }\end{array}$ & & $\begin{array}{c}\text { Facial type of } 28.1 \% \text { was assessed } \\
\text { to be brachyfacial and } 60.3 \% \text { were dental class II. } \\
\text { SB subjects showed a lower prevalence of } \\
\text { posterior crossbite compared with CTL subjects } \\
\text { (15.5\% } \\
\text { vs. } 33.8 \% \text {, respectively; P }=0.006) \text {. } \\
12.1 \% \text { of SB subjects reported } \\
\text { with } \\
\text { experiencing frequent headaches in comparison } \\
\text { Jawmuscle fatigue in } 10.3 \% \text {. } \\
\text { Tooth wear }-14 \%\end{array}$ \\
\hline $\begin{array}{l}\text { Maryam } \\
\text { Ghafour- } \\
\text { nia23 }\end{array}$ & 2012 & Iran & 6-Mar & 400 & $\begin{array}{c}\text { Cross } \\
\text { sectional }\end{array}$ & $\begin{array}{l}\text { Demir et al 16question- } \\
\text { naire } \\
\text { Intraoral examination }\end{array}$ & & $\begin{array}{c}\text { Flush terminal plane }-38 \% \text { in bruxism } \\
\text { Mesial Step } 50 \% \\
\text { Canine class } 1=8 \% \\
\text { Canine class } \mathrm{II}=2 \% \\
\text { Canine class } \mathrm{III}=2 \% \\
\text { Anterior and Posterior Crossbite }=2 \%\end{array}$ \\
\hline $\begin{array}{l}\text { Emodi Perl- } \\
\operatorname{man} 24\end{array}$ & 2012 & Israel & 12-May & 559 & & $\begin{array}{l}\text { AASM CRITERIA-Par- } \\
\text { ent's report } \\
\text { Examination:TMJ sounds } \\
\text { TMJ sensitivity to palpa- } \\
\text { tion } \\
\text { Sensitivity of Temporalis } \\
\text { and Masseter muscle } \\
\text { Pain assessed using faces } \\
\text { pain rating scale } \\
\text { Wear facet examination: } \\
\text { Johanson et al } \\
\end{array}$ & & $\begin{array}{c}\text { Tooth attrition Grade } 156.1 \% \text { Mandibular } \\
\text { molars } \\
53.3 \% \text { Canines } \\
45.9 \% \text { Incisors } \\
\text { Grade } 2 \& 3 \\
22.6 \% \text { Primary Canine } \\
12.7 \text { primary anterior } \\
10.6 \% \text { primary molar } \\
\text { Linea Alba } \\
\text { Tongue indentations }\end{array}$ \\
\hline $\begin{array}{l}\text { Tatiana } \\
\text { Helena Jun- } \\
\text { queira25 }\end{array}$ & 2013 & Brazil & $2-6$ years & 937 & $\begin{array}{l}\text { Cohort } \\
\text { study }\end{array}$ & $\begin{array}{c}\text { Parental Questionnaire } \\
\text { regarding bruxism in } \\
\text { children. } \\
\text { Clinical examination was } \\
\text { done to classify the rela- } \\
\text { tionship between the pri- } \\
\text { mary second molars based } \\
\text { on criteria of Baume26 }\end{array}$ & $29.30 \%$ & $\begin{array}{l}25.7 \% \text { presented a mesial step terminal relation- } \\
\text { ship at the primary second molars, } 29.1 \% \text { had } \\
\text { Distal Step, and } 30.2 \% \text { had Vertical Plane }\end{array}$ \\
\hline
\end{tabular}




\begin{tabular}{|c|c|c|c|c|c|c|c|}
\hline $\begin{array}{l}\text { B. de L. } \\
\text { Lucas18 }\end{array}$ & 2014 & Brazil & $6-8$ years & 40 & $\begin{array}{c}\text { Minimal criteria of the } \\
\text { International Classification } \\
\text { of Sleep Disorders for } \\
\text { Sleep bruxism } \\
\end{array}$ & & $\begin{array}{l}\text { The comparison of muscle activity between } \\
\text { groups showed no significant difference for both } \\
\text { masseter and anterior temporalis at Rest and } \\
\text { Maximum intercuspal position. }\end{array}$ \\
\hline $\begin{array}{l}\text { Ana Carla } \\
\text { Raphael- } \\
\text { liNahás- } \\
\text { Scocate27 }\end{array}$ & 2014 & Brazil & $\begin{array}{l}2 \text { years } 1 \\
\text { month to } \\
6 \text { years } 11 \\
\text { months }\end{array}$ & 873 & $\begin{array}{l}\text { Based on the question- } \\
\text { naire, the presence of } \\
\text { bruxism (yes or no), the } \\
\text { period in which the child } \\
\text { presented the parafunc- } \\
\text { tional habit (daytime, } \\
\text { night time or both), and } \\
\text { the variables related to } \\
\text { the presence of restless } \\
\text { sleep (yes or no) as well as } \\
\text { headaches (yes or no) were } \\
\text { investigated. } \\
\end{array}$ & $\begin{array}{c}\mathrm{M}=30.5 \% \\
\mathrm{~F}=27 \%\end{array}$ & $\begin{array}{l}38.4 \% \text { reported to have headache and showed } \\
\text { signs of bruxism, whereas } 26.1 \% \text { reported hav- } \\
\text { ing no headache even though they showed signs } \\
\text { of bruxism. Children without posterior crossbite } \\
\text { were } 2.2 \text { times more likely to have bruxism in } \\
\text { comparison to children with posterior crossbite. } \\
\text { Children who complained of having headaches } \\
\text { were } 1.5 \text { times more likely ( } 50 \% \text { more) to de- } \\
\text { velop bruxism, in comparison to those who did } \\
\text { not have headaches. No } \\
\text { significant relationship between this parafunc- } \\
\text { tional habit and the transverse plane of occlusion }\end{array}$ \\
\hline $\begin{array}{l}\text { Nashalie } \\
\text { Andrade de } \\
\text { Alencar28 }\end{array}$ & 2016 & Brazil & 3 to 7 years & $\begin{array}{l}66 \\
34 \text { CON- } \\
\text { TROL } \\
32 \\
\text { Test }\end{array}$ & $\begin{array}{l}\text { American Academy of } \\
\text { Sleep } \\
\text { Medicine (AASM) } \\
\text { The masseter muscle } \\
\text { activity was evaluated by } \\
\text { electromyography } \\
\text { examination (EMG) } \\
\text { A modification in the } \\
\text { Research Diagnostic } \\
\text { Criteria for } \\
\text { Temporomandibular } \\
\text { Disorders (RDC/TMD) } \\
\text { Axis II }\end{array}$ & $\begin{array}{c}32.80 \% \\
420 \text { of } \\
839\end{array}$ & $\begin{array}{c}\text { Drooling no association with bruxism. } \\
\text { 'Child wakes up in bad mood,' } \\
\text { 'Child feels tired or has painful jaw in the morn- } \\
\text { ing') compared } \\
\text { to children without bruxism }(\mathrm{p}<0.05) \\
\text { However, children with bruxism have more } \\
\text { headaches and } \\
\text { facial pain, and consequently, a sad appearance } \\
\quad(\mathrm{p}<0.05) \\
\text { Facial pain with sad appaearance }\end{array}$ \\
\hline $\begin{array}{c}\text { Carolina } \\
\text { CarvalhoB- } \\
\text { ortoletto29 }\end{array}$ & 2017 & Brazil & 3 to 6 years & 103 & $\begin{array}{l}\text { The first one consisted of } \\
\text { a specific questionnaire, } \\
\text { which was sent to parents } \\
\text { through the } \\
\text { school, and a chart, to be } \\
\text { filled in over three days, } \\
\text { detailing the child's sleep } \\
\text { characteristics. Three days } \\
\text { after the questionnaire } \\
\text { had been } \\
\text { sent out, parents were sent } \\
\text { a reminder, asking them } \\
\text { to return it. The second } \\
\text { stage consisted of a clinical } \\
\text { examination. } \\
\text {. During clinical examina- } \\
\text { tion, teeth were examined } \\
\text { for presence or absence } \\
\text { of wear facets, tongue was } \\
\text { examined for bite } \\
\text { marks, and the jugal mu- } \\
\text { cosa was assessed for bites } \\
\text { and linea alba. }\end{array}$ & $47.60 \%$ & $\begin{array}{l}\text { In relation to presence of headaches, we } \\
\text { observed a statistically significant difference } \\
\text { ( } \mathrm{p}=0.0086) \text {, whereby } 59.2 \% \text { of } \mathrm{SB} \text { children had } \\
\text { headaches, while among children without } \mathrm{SB} \text {, this } \\
\text { number fell to } 31.4 \% \text {. Headaches also occurred } \\
\text { more frequently in the children with } \\
\mathrm{SB} \text { than in the children without } \mathrm{SB}(\mathrm{p}=0.0369) \text {. } \\
\text { When evaluating the odds ratio, we observed } \\
\text { children with SB were almost three times } \\
2 \\
\text { more likely to have headaches than children with- } \\
\text { out } \mathrm{SB}(\mathrm{OR}=3.07 \text {; confidence interval } 1.36-6.9) \text {. }\end{array}$ \\
\hline
\end{tabular}

Table 2. Assessment of the quality of the case control studies according to the NEWCASTLE - OTTAWA SCALE.

\begin{tabular}{|c|c|c|c|c|c|c|c|c|}
\hline \multirow[t]{2}{*}{ Author } & \multicolumn{4}{|c|}{ Selection } & \multirow{2}{*}{$\begin{array}{c}\text { Comparability } \\
\text { Comparability } \\
\text { of cases and } \\
\text { controls }\end{array}$} & \multicolumn{3}{|c|}{ Exposure } \\
\hline & $\begin{array}{l}\text { Is the case } \\
\text { definition } \\
\text { adequate? }\end{array}$ & $\begin{array}{l}\text { Representa- } \\
\text { tiveness of } \\
\text { the case }\end{array}$ & $\begin{array}{c}\text { Selection of } \\
\text { controls }\end{array}$ & $\begin{array}{l}\text { Definition } \\
\text { of controls }\end{array}$ & & $\begin{array}{l}\text { Ascertain- } \\
\text { ment of } \\
\text { exposure }\end{array}$ & $\begin{array}{l}\text { Same method of } \\
\text { ascertainment } \\
\text { for cases and } \\
\text { controls }\end{array}$ & $\begin{array}{l}\text { Non-re- } \\
\text { sponse rate }\end{array}$ \\
\hline $\begin{array}{l}\text { C. C. RESTREPO } \\
\text { (2008) } 20\end{array}$ & $*$ & $*$ & $*$ & $*$ & $*$ & & * & \\
\hline $\begin{array}{l}\text { Nashalie Andrade de } \\
\text { Alencar } \\
-2016\end{array}$ & $*$ & & $*$ & $*$ & $*$ & & $*$ & $*$ \\
\hline $\begin{array}{l}\text { B.deL.Lucas } \\
\text { (2014)18 }\end{array}$ & $*$ & $*$ & $*$ & $*$ & $*$ & $*$ & $*$ & \\
\hline $\begin{array}{l}\text { Maryam Ghafournia } \\
\text { (2012)23 }\end{array}$ & $*$ & $*$ & $*$ & $*$ & & & $*$ & \\
\hline $\begin{array}{c}\text { Carra MC, Huynh N } \\
\text { (2011) } 22\end{array}$ & $*$ & $*$ & $*$ & & $*$ & & & \\
\hline $\begin{array}{c}\text { Edward V .Kuch } \\
\text { (1979) } 19\end{array}$ & $*$ & $*$ & $*$ & $*$ & $*$ & & $*$ & \\
\hline
\end{tabular}


Table 3. Assessment of the quality of the cohort studies according to the NEWCASTLE - OTTAWA QUALITY ASSESSMENT SCALE.

\begin{tabular}{|c|c|c|c|c|c|c|c|c|}
\hline \multirow[b]{2}{*}{ Author } & \multicolumn{4}{|c|}{ Selection } & \multirow{2}{*}{$\begin{array}{l}\text { Comparability } \\
\text { Comparability } \\
\text { of cohorts }\end{array}$} & \multicolumn{3}{|c|}{ Outcome } \\
\hline & $\begin{array}{l}\text { Representa- } \\
\text { tiveness of } \\
\text { exposed } \\
\text { cohort }\end{array}$ & $\begin{array}{l}\text { selection } \\
\text { of non- } \\
\text { exposed } \\
\text { cohorts }\end{array}$ & $\begin{array}{l}\text { Ascertain- } \\
\text { ment of } \\
\text { exposure }\end{array}$ & $\begin{array}{l}\text { Demonstration } \\
\text { that outcome of } \\
\text { interest was not } \\
\text { present at the start } \\
\text { of the study }\end{array}$ & & $\begin{array}{l}\text { Assessment } \\
\text { of Outcome }\end{array}$ & $\begin{array}{l}\text { Was follow up } \\
\text { long enough } \\
\text { for outcome to } \\
\text { occur }\end{array}$ & $\begin{array}{l}\text { Adequacy } \\
\text { of follow up } \\
\text { of cohorts }\end{array}$ \\
\hline $\begin{array}{c}\text { Ana Carla Raphaelli- } \\
\text { Nahás-Scocate (2014)27 }\end{array}$ & * & * & * & & & * & & \\
\hline $\begin{array}{l}\text { BahmanSeraj } \\
\text { (2010)21 }\end{array}$ & * & * & * & & $*$ & * & & \\
\hline $\begin{array}{c}\text { Carolina CarvalhoBor- } \\
\text { toletto }-2017\end{array}$ & * & * & * & & & $*$ & & \\
\hline $\begin{array}{l}\text { Emodi Perlman } \\
\text { (2012)24 }\end{array}$ & * & * & $*$ & * & & $*$ & & \\
\hline $\begin{array}{l}\text { Tatiana Helena Jun- } \\
\text { queira(2013) } 25\end{array}$ & $*$ & * & $*$ & & & $*$ & & \\
\hline
\end{tabular}

Figure 1. PRISMA FLOWCHART.

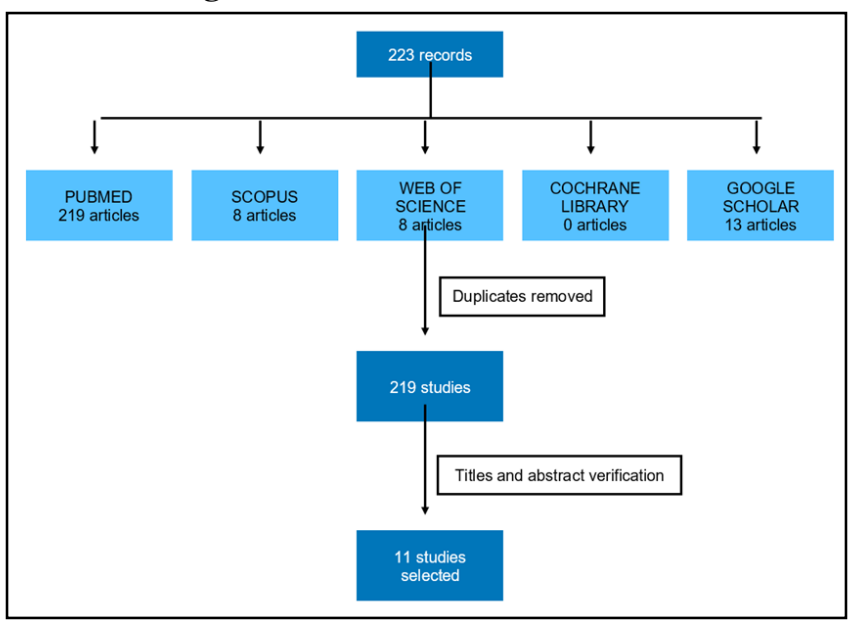

and occlusal relationship such as flush terminal plane, mesial step, anterior and posterior crossbite.

Emodi Perlman (2012) [24] is a cohort study assessed 559 children for parafunctional habits and its association with anamnestic and clinical findings of TMD and possible impact of stressful life on the parafunctional habit. The present study showed stressful life showing increased association with the prevalence of parafunctional habits, however, bruxism was not associated with anamnestic and clinical findings of TMDs.

Tatiana Helena Junqueira (2012) [25] is a cohort study showing children with headache and restless sleep showed higher chance of presenting with bruxism. Children with bruxism showed higher prevalence of mesial step relationship.

Ana Carla Raphaelli Nahás-Scocate (2014) is a cross-sectional study which examined 873 children through questionnaire and clinical examination for bruxism and its corresponding effects on the occlusal characteristics in the transverse directions. This study showed $28.8 \%$ prevalence of bruxism habit, however, there was no significant difference between bruxers and prevalence of crossbites.

B.deL.Lucas (2014 [18] is a case control study which compared muscle activity between bruxers and non-bruxers. This study found no significant increase in the muscle activity in children with presence of bruxism.

Nashalie Andrade de Alencar (2016) [28] is a case control study that reported 34 children with bruxism compared with 32 nonbruxers. The outcomes of the child's routine during the day, during sleep and awakening, headache frequency, temporomandibular joint (TMJ), and hearing impairments were assessed using questionnaire. In addition, electromyography was done to assess the activity of facial muscles. There was a positive association between bruxism and nightmares, snoring, orofacial pain and headache.

Carolina CarvalhoBortoletto (2017) [29] is a cohort study conducted on 103 children aged 3-6 years. The present study evaluates the presence of sleep bruxism using the criteria given by American Academy of Sleep Medicine and the quality of sleep was evaluated using questionnaires. $47.6 \%$ of children showed sleep bruxism with 3.25 fold children more likely to be present with headache. This study does not report presence of headache associated with clenching teeth in the morning.

\section{Discussion}

Bruxism is an oral habit which is characterized by habitual clenching and grinding of teeth. It is associated with severe wear of the dentition as well as affects muscle and joint apparatus. In addition, 
it increases the risk of traumatic dental injuries and increases the progression of the periodontal diseases.

Bruxism is a Para-functional habit that possesses a multifactorial etiology. Its cause is related to genetics, premature occlusal interference, psychological and behavioral factors, increased overjet, overbite, open bite and crossbite. In addition Temporomandibular Joint disorder is also associated with the etiology of bruxism. These craniofacial factors are the cause as well as effect of the bruxism. Hence, the present systematic review evaluates the effect on craniofacial factors associated with bruxism.

The present systematic review includes 11 studies based on the pre-determined inclusion and exclusion criteria. These studies were either cohort studies or case control studies.

For cohort and cross-sectional studies the outcome was assessed using questionnaires which assessed the history and characteristics of the habit. In addition these studies also reported the prevalence of bruxism among the population. These characteristics of bruxism were co-related with the occlusal features in the dental arch. In addition ASSM criteria was also used to evaluate the pain and tenderness in the temporomandibular joints associated with bruxism which was co-related with presence of occlusal facets.

The outcome for case control studies, ASSM criteria was used. This compared outcomes between the children with bruxism and children without bruxism. Another study by B.deL.Lucas [18] used the EMG of masticatory muscles and compared with morphologic occlusion between the children with bruxism and children without bruxism. Nashalie Andrade de Alencar used both AASM criteria as well as EMG in addition to presence or absence of headache compared with occlusal factors between children with bruxism and children without bruxism. In study by Carra MC, Huynh N4 the craniofacial changes were evaluated based on the presence of overjet, overbite, crossbites and facial profiles between children with bruxism and children without bruxism.

The included studies showed prevalence of bruxism from 30$47.6 \%$ varying among different populations. According to Edward $\mathrm{V}$.Kuch, [19] wear facets were observed in children with bruxism. In addition to wear facets, pain and tenderness in the masticatory muscle and increased headache was reported in children with bruxism. This was a contradictory finding in another study by B.deL.Lucas who reported no significant difference in pain and tenderness of masticatory muscles and headache between children with bruxism and those without. Another contradictory report was found between the occlusal relationship in children with bruxism. A study by Maryam Ghafournia [23] reported higher number of mesial step relationship in children with bruxism as compared to the study by Tatiana Helena Junqueira [25] reported no significant difference between children with bruxism and their terminal relationships. In addition, a study by C. C. RESTREPO [20] reported children with bruxism to have high arch palate as a craniofacial abnormality. Also, studies by Carra MC, Huynh N4 and Ana Carla Raphaelli Nahás-Scocate [27] reported children with bruxism to have increased presence of crossbites.

Since there is a contradictory result from different studies regarding the outcomes of terminal relationship and presence of muscle tenderness, pain and headache, further studies giving a more definitive insight to these outcomes should be conducted. A major limitation of the present systematic review is that it selects article evaluating only the effect on craniofacial structures. Bruxism being a multifactorial disorder, incorporating more etiological factors and multiple outcomes can give an overall outlook to the parafunctional habit.

\section{References}

[1]. Bader G, Lavigne G. Sleep bruxism; an overview of an oromandibular sleep movement disorder. REVIEW ARTICLE. Sleep Med Rev. 2000 Feb;4(1):27-43. PMID: 12531159.

[2]. Manfredini D, Restrepo C, Diaz-Serrano K, Winocur E, Lobbezoo F. Prevalence of sleep bruxism in children: a systematic review of the literature. J Oral Rehabil. 2013 Aug;40(8):631-42. PMID: 23700983.

[3]. Lavigne G, Kato T. Usual and unusual orofacial motor activities associated with tooth wear. Int J Prosthodont. 2005 Jul-Aug; 18(4): 291-2. PMID: 16052775.

[4]. Carra MC, Huynh N, Morton P, Rompré PH, Papadakis A, Remise C, et al. Prevalence and risk factors of sleep bruxism and wake-time tooth clenching in a 7- to 17-yr-old population. Eur J Oral Sci. 2011 Oct;119(5):386-94. PMID: 21896056

[5]. Kato T, Masuda Y, Yoshida A, Morimoto T. Masseter EMG activity during sleep and sleep bruxism. Arch Ital Biol. 2011 Nov 7;149(4):478-91. PMID: 22205593.

[6]. Molina OF, dos Santos J, Mazzetto M, Nelson S, Nowlin T, Mainieri ET Oral jaw behaviors in TMD and bruxism: a comparison study by severity of bruxism. Cranio. 2001 Apr;19(2): 114-22. PMID: 11842862.

[7]. Serra-Negra JM, Paiva SM, Auad SM, Ramos-Jorge ML, Pordeus IA. Signs, symptoms, parafunctions and associated factors of parent-reported sleep bruxism in children: a case-control study. Braz Dent J. 2012;23(6):746-52. PMID: 23338271.

[8]. Sjöholm TT, Lowe AA, Miyamoto K, Fleetham JA, Ryan CF. Sleep bruxism in patients with sleep-disordered breathing. Arch Oral Biol. 2000 Oct;45(10):889-96. PMID: 10973562.

[9]. Ohayon MM, Li KK, Guilleminault C. Risk factors for sleep bruxism in the general population. Chest. 2001 Jan;119(1):53-61. PMID: 11157584.

[10]. Sheldon SH. Obstructive sleep apnea and bruxism in children. Sleep Medicine Clinics. 2010 Mar 1; 5(1): 163-8.

[11]. Nilner M, Lassing SA. Prevalence of functional disturbances and diseases of the stomatognathic system in 7-14 year olds. Swed Dent J. 1981;5(5-6): 173-87. PMID: 6949326.

[12]. Ahmad R. Bruxism in children. The Journal ofpedodontics. 1986; 10(2): 105-26.

[13]. Loos PJ, Aaron GA. Standards for management of the pediatric patient with acute pain in the temporomandibular joint or muscles of mastication. Pediatric dentistry. 1989 Dec; 11(4): 331.

[14]. DiFrancesco RC, Junqueira PA, Trezza PM, de Faria ME, Frizzarini R, Zerati FE. Improvement of bruxism after T \& A surgery. Int J PediatrOtorhinolaryngol. 2004 Apr;68(4):441-5. PMID: 15013611.

[15]. Sateia MJ. International classification of sleep disorders-third edition: highlights and modifications. Chest. 2014 Nov;146(5):1387-1394. PMID: 25367475.

[16]. Demir A, Uysal T, Guray E, Basciftci FA. The relationship between bruxism and occlusal factors among seven- to 19-year-old Turkish children. Angle Orthod. 2004 Oct;74(5):672-6. PMID: 15529503.

[17]. Peterson J, Welch V, Losos M, Tugwell PJ. The Newcastle-Ottawa scale (NOS) for assessing the quality of nonrandomised studies in meta-analyses. Ottawa: Ottawa Hospital Research Institute. 2011.

[18]. Lucas Bde L, Barbosa Tde S, Pereira LJ, Gavião MB, Castelo PM. Electromyographic evaluation of masticatory muscles at rest and maximal intercuspal positions of the mandible in children with sleep bruxism. Eur Arch Paediatr Dent. 2014 Aug;15(4):269-74. PMID: 24599796.

[19]. Kuch EV, Till MJ, Messer LB. Bruxing and non-bruxing children: a comparison of their personality traits. Pediatr Dent. 1979 Sep;1(3):182-7. PMID: 298759.

[20]. Restrepo CC, Sforza C, Colombo A, Peláez-Vargas A, Ferrario VF. Palate morphology of bruxist children with mixed dentition. A pilot study. J Oral Rehabil. 2008 May;35(5):353-60. PMID: 18405271.

[21]. Seraj B, Shahrabi M, Ghadimi S, Ahmadi R, Nikfarjam J, Zayeri F, et al. The Prevalence of Bruxism and Correlated Factors in Children Referred to Dental Schools of Tehran, Based on Parent's Report. Iran J Pediatr. 2010 Jun;20(2):174-80. PMID: 23056700.

[22]. Carra MC, Huynh N, Morton P, Rompré PH, Papadakis A, Remise C, et al. Prevalence and risk factors of sleep bruxism and wake-time tooth clenching in a 7- to 17-yr-old population. Eur J Oral Sci. 2011 Oct;119(5):386-94. 
PMID: 21896056.

[23]. Ghafournia M, HajenourozaliTehrani M. Relationship between Bruxism and Malocclusion among Preschool Children in Isfahan. J Dent Res Dent Clin Dent Prospects. 2012 Fall;6(4):138-42. PMID: 23277860.

[24]. Emodi-Perlman A, Eli I, Friedman-Rubin P, Goldsmith C, Reiter S, Winocur E. Bruxism, oral parafunctions, anamnestic and clinical findings of temporomandibular disorders in children. J Oral Rehabil. 2012 Feb;39(2):12635. PMID: 21916926.

[25]. Junqueira TH, Nahás-Scocate AC, Valle-Corotti KM, Conti AC, Trevisan S. Association of infantile bruxism and the terminal relationships of the primary second molars. Braz Oral Res. 2013 Jan-Feb;27(1):42-7. PMID: 23306625.

[26]. BAUME LJ. Physiological tooth migration and its significance for the development of occlusion. I. The biogenetic course of the deciduous dentition. J
Dent Res. 1950 Apr;29(2):123-32. PMID: 15415484.

[27]. Nahás-Scocate AC, Coelho FV, de Almeida VC. Bruxism in children and transverse plane of occlusion: is there a relationship or not? Dental Press J Orthod. 2014 Sep-Oct;19(5):67-73. PMID: 25715718

[28]. de Alencar NA, Leão CS, Leão ATT, Luiz RR, Fonseca-Gonçalves A, Maia LC. Sleep Bruxism and Anxiety Impacts in Quality of Life Related to Oral Health of Brazilian Children and their Families. J ClinPediatr Dent. 2017;41(3):179-185. PMID: 28422599.

[29]. Bortoletto CC, Salgueiro MDCC, Valio R, Fragoso YD, Motta PB, Motta LJ, et al. The relationship between bruxism, sleep quality, and headaches in schoolchildren. J PhysTher Sci. 2017 Nov;29(11):1889-1892. PMID: 29200617. 